UNDERGROUND MINING ENGINEERING 35 (2019) 23-35 $\quad$ UDK 62

Original scientific paper

\title{
COPPER MINERALS FLOTATION IN FLOTATION PLANT OF THE "RUDNIK" MINE
}

\author{
Predrag Lazić1 ${ }^{\text {, Đurica Nikšić1 }}$, Branislav Miković1 ${ }^{\text {, Rudolf Tomanec }}{ }^{1}$
}

Received: October 23, 2019

Accepted: November 1, 2019

\begin{abstract}
A unique technology of direct selective flotation is in use in flotation plant of the "Rudnik" mine in order to obtain selective lead, copper and zinc concentrates. Technological process is very sensitive to so-called "selectivity" because loss of individual metals through selective concentrates is present. Copper minerals flotation cycle is especially sensitive to selectivity and sometimes there is a higher content of lead and zinc minerals present in copper concentrate which is penalized. In this paper laboratory research results of lowering galena and zinc content in copper concentrate possibility due to extended time of cleaning are shown. All experiments were carried out on copper concentrate samples taken from the "Rudnik" flotation plant. Copper concentrate mineralogical analysis were carried out before flotation experiments.
\end{abstract}

Keywords: selective flotation; copper minerals; penalized elements;

\section{INTRODUCTION}

Research results, presented in this paper, shows determination of lowering main harmful (lead and zinc) elements content possibility in copper concentrate. Contents of lead and zinc, in examination copper concentrate, were 4,4-4,86\% of $\mathrm{Pb}$ and 5,3-9,3\% of $\mathrm{Zn}$.

Each smelter requires different copper concentrate quality in term of impurities content limitations. Typical limitations of impurities content in copper concentrate and penalties for exceeding content are shown in Table 1. (Friedberg \& Robinson, 2015; Weidenbach et al., 2016)

\footnotetext{
${ }^{1}$ University of Belgrade - Faculty of Mining and Geology

Emails: predrag.lazic@rgf.bg.ac.rs; djurica.niksic@rgf.bg.ac.rs; branislav.mikovic@rgf.bg.ac.rs; rudolf.tomanec@rgf.bg.ac.rs
} 
Table 1 Typical impurities content limitations in copper concentrate

\begin{tabular}{cc}
\hline Element & Penalty limit [\%] \\
\hline Arsenic & 0.2 \\
Higher Arsenic & $>1$ \\
Antimony & 0.05 \\
Bismuth & 0.02 \\
Cadmium & 0.03 \\
Fluorine & 0.03 \\
Lead & 1 \\
Mercury & 0.0005 \\
Nickel + Cobalt & 0.5 \\
Selenium & 0.03 \\
Zinc & 3 \\
\hline
\end{tabular}

Impurities content (lead and zinc) in examined copper concentrate is 3-4 times higher than limitation showed in Table 1. Content of other impurities present in examined copper concentrate is below penalty limits.

Flotation is used to selectively separate particles (minerals) based on their surface properties which were modified by flotation reagents. (Leppinen et al., 1998; Bulatovic, 2007; Long et al., 2014; Bournival et al., 2014; Chen et al., 2019; Ran et al., 2019; Zanin et al., 2019).

Researches were focused on the flotation selectivity increase during copper concentrate cleaning stage in flotation plant of the "Rudnik" mine. Microscopic analysis of harmful elements appearance in copper concentrate was the basis for further researches.

Procedures and research results of content and distribution of lead, copper and zinc by size fractions in copper concentrate are shown. Also, mineralogical (microscopic) analysis of copper concentrate by size fractions results are shown.

Cleaning copper concentrate experiments were carried out after the above-mentioned examinations. Those experiments had a goal to determine possibility of better results achievement by application of one additional copper concentrate cleaning stage in the industrial flotation plant. Influence of cleaning time duration and pulp density on concentrate quality were examined, without use of flotation reagents except for frothing reagents and $\mathrm{pH}$ regulators. Comments on all obtained results, conclusions and used literature are shown at the end of paper. 


\section{SAMPLE AND RESEARCH METHODS}

All researches, shown in this paper, were carried out on composite copper concentrate sample from flotation plant of the "Rudnik" mine.

\subsection{Particle size distribution determination procedure}

Based on the fact that copper concentrate contains particles which are all below $100 \mu \mathrm{m}$, particle size distribution is determined by wet sieving on Tyler sieve series. Sieve openings were $0.074 \mathrm{~mm}$ and $0.038 \mathrm{~mm}$. Particles below $0.038 \mathrm{~mm}$ were treated by sedimentation method (Beaker decantation). Mass measurement was performed after drying, and examination results are presented in Table 2 and graphically (Fig. 1).

\subsubsection{Beaker decantation metod}

"Beaker decantation" is the most commonly used method to determine particle size distribution and size fractions extraction of particles size below $38 \mu \mathrm{m}$. (Tomanec, 2000)

Determination of particles settling rate by Stokes law is necessary for this method:

$$
\mathrm{v}_{\mathrm{o}}=545(\gamma-1) \mathrm{d}^{2}
$$

Where:

$$
\begin{aligned}
& \mathrm{v}_{\mathrm{o}} \text { - settling rate, }[\mathrm{mm} / \mathrm{s}] \\
& \gamma \text { - mineral density, }\left[\mathrm{t} / \mathrm{m}^{3}\right] \\
& \mathrm{d} \text { - particle size }[\mathrm{mm}]
\end{aligned}
$$

Settling time of certain size fraction (d) is determined by formula:

$$
\mathrm{t}=\mathrm{H} / \mathrm{v}_{\mathrm{o}} \cdot 1,05
$$

Where:

$$
\begin{aligned}
& \mathrm{t}-\text { settling time, }\left[\mathrm{t} / \mathrm{m}^{3}\right] \\
& \mathrm{v}_{\mathrm{o}}-\text { mineral settling rate, }[\mathrm{mm} / \mathrm{s}] \\
& \mathrm{H} \text { - suspension height }[\mathrm{mm}]
\end{aligned}
$$

Copper concentrate was analyzed according to galena density $\left(\gamma=7,6 \mathrm{t} / \mathrm{m}^{3}\right)$, by calculating the equivalent diameter and two size fractions were produced: $0,018 \mathrm{~mm}(18$ $\mu \mathrm{m})$ and $0,009 \mathrm{~mm}(9 \mu \mathrm{m})$.

\subsection{DETERMINATION OF METALS AND MINERALS DISTRIBUTION BY SIZE FRACTIONS}

Rational analysis was performed on the base of obtained size fractions metal content, in fact, by recalculating metals content to minerals with assumption that all of copper is bonded to chalcopyrite, lead to galena and zinc to sphalerite. (Tomanec at al., 2012, 2013) 


\subsection{Microscopic analysis}

Microscopic analysis was performed on copper concentrate samples with the aim to determine harmful (penalizing) minerals appearance by size fractions.

\subsection{Copper concentrate flotation experiments}

Flotation experiments in function of extended cleaning time of copper concentrate were carried out, according to research goal. Determination possibility of achievement better copper concentrate quality due to extended cleaning time was the goal of the research.

Flotation experiments of cleaning copper concentrate were carried out by the following conditions: in function of cleaning time (1,2 and $3 \mathrm{~min})$ with solid-in-pulp concentration of 14\%: This laboratory researches were carried out on laboratory flotation machine "DENVER" with flotation cell volume of $2,8 \mathrm{dm}^{3},(14 \% \mathrm{~S})$; in this cell conditioning at $1200 \mathrm{r} / \mathrm{min}$ and flotation at $1500 \mathrm{r} / \mathrm{min}$ were performed; Lime was used as $\mathrm{pH}$ regulator and dowfroth - 250 as frother; Flotation concentrates were filtered and dried.

\section{RESULTS AND DISCUSSION}

\subsection{Particle size distribution}

Particle size distribution was determined by wet sieving to $\mathrm{a}+38 \mu \mathrm{m}$ fractions and -38 $\mu \mathrm{m}$ fractions by "Beaker decantation" method.

Particle size distribution of chalcopyrite concentrate is shown in Table 2 and Fig. 1.

Table 2 Particle size distribution of chalcopyrite concentrate

\begin{tabular}{cccc}
\hline Size fraction $[\mathrm{mm}]$ & $\mathrm{Wt}, \%$ & $\downarrow \sum_{\mathrm{Wt}, \%} \uparrow \sum_{\mathrm{Wt}, \%}$ \\
\hline$-0.104+0.074$ & 12.52 & 12.52 & 100.00 \\
$-0.074+0.038$ & 57.50 & 70.02 & 87.48 \\
$-0.038+0.018$ & 4.31 & 74.33 & 29.98 \\
$-0.018+0.009$ & 16.43 & 90.76 & 25.67 \\
$-0.009+0.000$ & 9.24 & 100.00 & 9.24 \\
$\Sigma$ & 100.00 & $/$ & $/$ \\
\hline
\end{tabular}




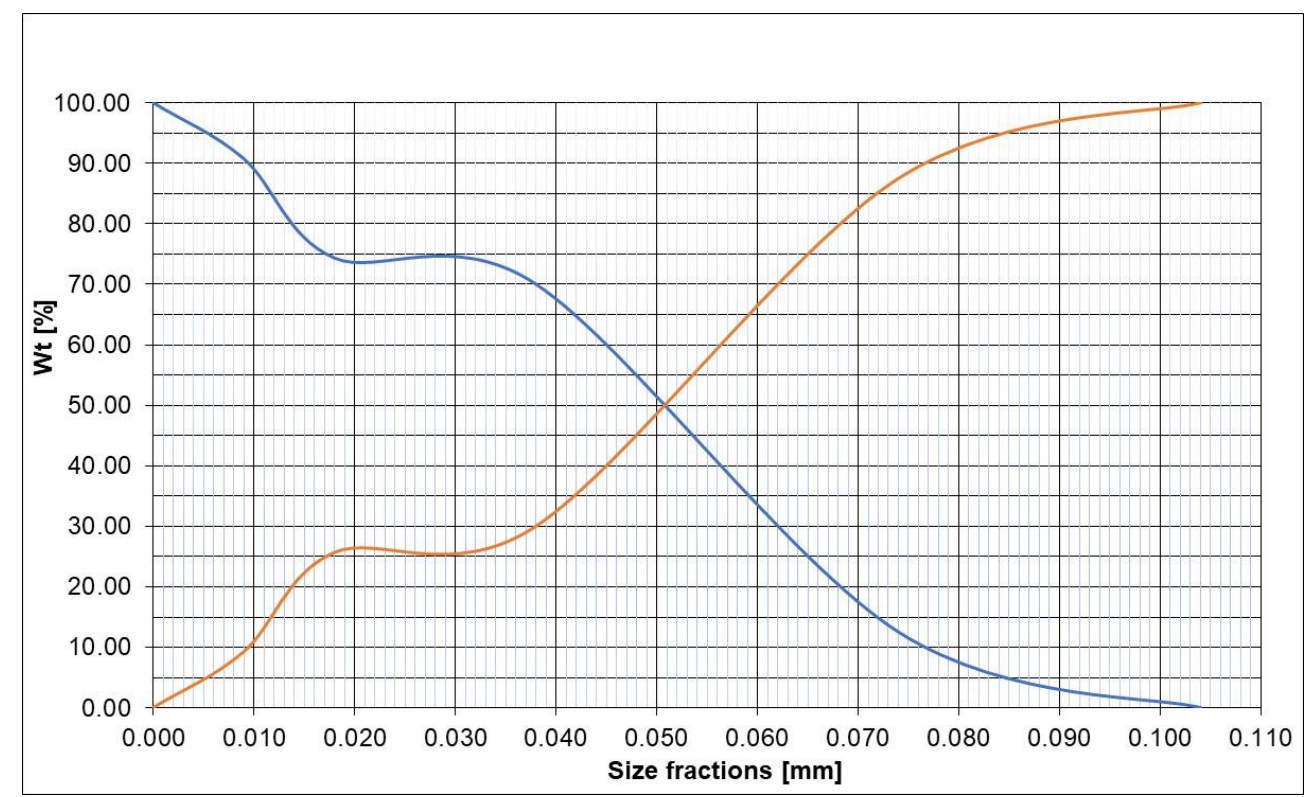

Figure 1 Particle size distribution of chalcopyrite concentrate

Based on particle size distribution analysis it can be concluded that copper concentrate is relatively finely milled $\left(87,48 \%\right.$ of $-0,074 \mathrm{~mm}$ fraction). Chalcopyrite concentrate $\mathrm{d}_{95}$ is approximately $0,082 \mathrm{~mm}$ and $\mathrm{d}_{50}$ is approximately $0,05 \mathrm{~mm}$. Content of $-0,009 \mathrm{~mm}$ fraction, which have poor flotation properties, is $9,24 \%$.

\subsection{Mineral distribution by size fractions}

Determination of mineral distribution by size fractions was carried out on copper concentrate by size fraction extraction, metals and minerals distribution analysis and by microscopic mineral appearance analysis.

\subsubsection{Mineral distribution by size fractions results disscusion}

Examined copper concentrate from flotation plant of the "Rudnik" mine contained 24\% of copper, 5,5\% of zinc and 4,5\% of lead. By copper content this is a high-quality concentrate. However, there is high content of penalty elements (lead and zinc) in copper concentrate. Microscopic analysis gave the following results, shown in Table 2. 
Lazić P., Nikšić Đ., Miković B., Tomanec R.

Table 2 Minerals and metals distribution by size fractions in copper concentrate

\begin{tabular}{|c|c|c|c|c|c|c|c|c|c|c|}
\hline $\begin{array}{c}\text { Size fraction, } \\
{[\mathrm{mm}]}\end{array}$ & $\begin{array}{c}\mathrm{Wt}, \\
\%\end{array}$ & $\underset{\%}{\mathrm{Cu}}$ & $\underset{\%}{\mathrm{CuFeS}_{2},}$ & $\begin{array}{c}\mathbf{R} \\
\underset{\%}{\mathrm{CuFeS}}, \\
\end{array}$ & $\underset{\%}{\mathrm{Zn}}$ & $\underset{\%}{\mathrm{ZnS}}$ & 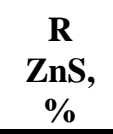 & $\begin{array}{c}\mathrm{Pb}, \\
\%\end{array}$ & $\begin{array}{c}\text { PbS, } \\
\%\end{array}$ & $\begin{array}{c}\mathbf{R} \\
\mathrm{PbS}, \\
\%\end{array}$ \\
\hline$-0,104+0,074$ & 12,52 & 15,21 & 43,96 & 7,95 & 6,04 & 9,00 & 13,64 & 6,65 & 7,68 & 18,72 \\
\hline$-0,074+0,038$ & 57,50 & 24,78 & 71,62 & 59,49 & 5,48 & 8,17 & 56,85 & 3,45 & 3,98 & 44,56 \\
\hline$-0,038+0,018$ & 4,31 & 19,78 & 57,17 & 3,56 & 4,77 & 7,11 & 3,71 & 2,82 & 3,26 & 2,74 \\
\hline$-0,018+0,009$ & 16,43 & 27,21 & 78,64 & 18,67 & 6,18 & 9,21 & 18,32 & 3,87 & 4,47 & 14,30 \\
\hline$-0,009+0,000$ & 9,24 & 26,78 & 77,40 & 10,33 & 4,49 & 6,69 & 7,48 & 9,47 & 10,94 & 19,68 \\
\hline Conc./CuFeS 2 & 100,00 & 23,95 & 69,22 & 100,00 & 5,54 & 8,26 & 100,00 & 4,40 & 5,13 & 100,00 \\
\hline
\end{tabular}

Metals and minerals distribution in $-0,104+0,074 \mathrm{~mm}$ fraction of copper concentrate

This size fraction-weight ratio, relative to $100 \%$ copper concentrate, is $12,52 \%$. Metals content in this fraction is $6,04 \%$ of $\mathrm{Zn}, 15,21 \%$ of $\mathrm{Cu}$ and $6,65 \%$ of $\mathrm{Pb}$. Mineral distribution in this fraction is $13,64 \%$ of $\mathrm{ZnS}, 7,95 \%$ of $\mathrm{CuFeS}_{2}$ and $18,72 \%$ of $\mathrm{PbS}$. Sphalerite content in this fraction is slightly higher relative to comprehensive copper concentrate. Also, galena content is $7,68 \%$, i.e. $2,55 \%$ higher than in concentrate. Chalcopyrite content is $43,96 \%$, i.e. $26 \%$ lower than in concentrate.

Microscopic analysis of polished specimen determined that in this fraction mostly intergrowth particles are present, i.e. poly-mineral crystal aggregates made of mostly idiomorphic quartz, pyrrhotite, sphalerite and small amount of galena. This size fraction is optimal for flotation process and very small amount of free galena and sphalerite particles is present. (George et al., 2004; Gontijo et al., 2007; Ata \& Jameson, 2013; Cveticanin, 2017; Kohmuench et al., 2018; Maknosa et al., 2018; Jameson \& Emer, 2019) This galena and sphalerite particles could not be liberated without additional milling of ore. Due to complex structural-textural characteristic of one part of the ore, poly-mineral intergrowth particles are present in the milled ore and it could not be expected that at the optimum particles size fraction for flotation the presence of intergrowth particles could be avoided. (Tomanec, 2011)

\section{Metals and minerals distribution in $-\mathbf{0 , 0 7 4 + 0 , 0 3 8} \mathrm{mm}$ fraction of copper concentrate}

This size fraction-weight ratio is high, $57,5 \%$. Metal content in this fraction is $5,48 \%$ of $\mathrm{Zn}, 24,78 \%$ of $\mathrm{Cu}$ and $3,45 \%$ of $\mathrm{Pb}$. Mineral distribution in this fraction is $56,85 \%$ of $\mathrm{ZnS}, 59,49 \%$ of $\mathrm{CuFeS}_{2}$ and $44,56 \%$ of $\mathrm{PbS}$. Minerals distribution follows high weight ratio of this size fraction. Content of harmful minerals is $8,17 \%$ of $\mathrm{ZnS}$ and $3,98 \%$ of 
$\mathrm{PbS}$. This size fraction is optimal for selective copper minerals flotation process. (George et al., 2004; Gontijo et al., 2007; Ata \& Jameson, 2013; Cveticanin, 2017; Kohmuench et al., 2018; Maknosa et al., 2018; Jameson \& Emer, 2019)

In this size fraction chalcopyrite is appearing in mostly liberated particles form. In comparison with $-0,104+0,074 \mathrm{~mm}$ fraction chalcopyrite has significantly higher liberation degree. Besides liberated chalcopyrite particles there is appearance of liberated pyrrhotite particles. Also, in this size fraction pyrrhotite appears in intergrowth particles with sphalerite. Minerals ratio in this intergrowth particles is approximately equal. Galena rarely occurs. Estimated amount of liberated galena and sphalerite particles is approximately $15-18 \%$. With that in mind, it can be estimated that one additional stage of copper concentrate cleaning can lower content of unwanted minerals in final concentrate, which would improve the quality of the concentrate.

\section{Metals and minerals distribution in $-0,038+0,018 \mathrm{~mm}$ fraction of copper concentrate}

This size fraction-weight ratio is low 4,31\%, thus participation of this fraction in metals and minerals distribution is insignificant. This size fraction is suitable for flotation process.

\section{Metals and minerals distribution in $-0,018+0,009 \mathrm{~mm}$ fraction of copper concentrate}

This size fraction-weight ratio is $16,43 \%$. Metals content in this fraction is $6,18 \%$ of $\mathrm{Zn}$, $27,21 \%$ of $\mathrm{Cu}$ and $3,87 \%$ of $\mathrm{Pb}$. Minerals distribution in this fraction is $18,32 \%$ of marmatite and $14.3 \%$ of galena.

Microscopic examination results of this size fraction are similar to $-0,038+0,018 \mathrm{~mm}$ fraction. A very high content of liberated chalcopyrite particles is present. Also, significant content of sphalerite particles with $5-12 \%$ of chalcopyrite droplet intrusions. The presence of galena is very small.

In this size fraction all minerals particles are mostly liberated, and the particles size is still suitable for flotation. Based on that, it can be expected to determinate conditions for removing a part of unwanted minerals with additional cleaning stage of copper concentrate.

\section{Metals and minerals distribution in $-\mathbf{0 , 0 0 9 + 0 , 0} \mathbf{~ m m}$ fraction of copper concentrate}

This size fraction contains small size particles which demand more complex flotation conditions. Also, lower process selectivity can be expected. (George et al., 2004; Gontijo et al., 2007; Ata \& Jameson, 2013; Cveticanin, 2017; Kohmuench et al., 2018; Maknosa et al., 2018; Jameson \& Emer, 2019) Microscopic mineral identification is more 
complex. This size fraction has poor flotation rate in industrial flotation plants, thus the lowest content of this fraction in milled ore i.e. flotation pulp is desirable. This size fraction-weight ratio is $9,24 \%$ in copper concentrate. In this size fraction mineral content is $6.69 \%$ of sphalerite and approximately $11 \%$ of galena. Mineral distribution is approximately $7.5 \%$ of sphalerite and almost $20 \%$ of galena. This high difference in mineral distribution is due to galena extreme weariness, which easily converts into small particle sizes, which demands longer flotation time.

A high content of liberated chalcopyrite particles and significant amount of liberated galena particles are present. Present intergrowth particles were composed only of chalcopyrite and sphalerite.

\subsection{Copper concentrate cleaning}

Researches of copper concentrate quality improvement possibility were carried out in laboratory conditions by applying one additional stage of concentrate cleaning. Experiments were carried out in function of cleaning duration time with solid-in-pulp concentration of $14 \%$.

Exp. 1 t=1min.

$0.5 \mathrm{~kg}$ concentrate $(14 \% \mathrm{~S})$

$0.5 \mathrm{~g} \mathrm{CaO}$

$\mathrm{pH}=10$

$3 \mathrm{~g} / \mathrm{t} \mathrm{D}-250$

Exp. $2 \mathrm{t}=2 \mathrm{~min}$.

$0.5 \mathrm{~kg}$ concentrate $(14 \% \mathrm{~S})$

$0.4 \mathrm{~g} \mathrm{CaO}$

$\mathrm{pH}=9,3$

$3 \mathrm{~g} / \mathrm{t} \mathrm{D}-250$

Exp. $3 \mathrm{t}=3 \mathrm{~min}$.

$0.5 \mathrm{~kg}$ concentrate $(14 \% \mathrm{~S})$

$0.5 \mathrm{~g} \mathrm{CaO}$

$\mathrm{pH}=9,1$

$3 \mathrm{~g} / \mathrm{t} \mathrm{D}-250$

Chemical analysis results of flotation products are presented in Tables 3, 4 and 5, as metals balance. Metals recovery is calculated based on $100 \%$ recovery in starting copper 
concentrate sample (Copper average recovery in this flotation plant produced concentrate is approximately $64 \%$ ).

Table 3 Exp. 1 Conc./Cu Metal balance

\begin{tabular}{|c|c|c|c|c|c|c|c|}
\hline \multirow[b]{2}{*}{ Products } & \multirow[b]{2}{*}{$\mathrm{Wt}, \%$} & \multirow[b]{2}{*}{$\mathbf{P b}, \%$} & \multirow[b]{2}{*}{$\mathrm{Zn}, \%$} & \multirow[b]{2}{*}{$\mathrm{Cu}, \%$} & \multicolumn{3}{|c|}{$\begin{array}{c}\text { METAL } \\
\text { DISTRIBUTION } \\
\end{array}$} \\
\hline & & & & & $\mathbf{R}_{\mathbf{P b}} \%$ & $\mathrm{R}_{\mathrm{Zn}} \%$ & $\mathbf{R}_{\mathrm{Cu}} \%$ \\
\hline Rough conc./Cu & 100,00 & 4,86 & 5,31 & 27,03 & 100,00 & 100,00 & 100,00 \\
\hline Cleaned conc./Cu & 13,46 & 2,65 & 9,69 & 29,04 & 7,34 & 24,56 & 14,46 \\
\hline Middling conc./Cu & 86,54 & 5,20 & 4,63 & 26,72 & 72,66 & 75,44 & 85,54 \\
\hline
\end{tabular}

Table 4 Exp. 2 Conc./Cu Metal balance

\begin{tabular}{cccccccc}
\hline Products & $\mathbf{W t}, \boldsymbol{\%}$ & $\mathbf{P b}, \boldsymbol{\%}$ & $\mathbf{Z n , \%}$ & $\mathbf{C u}, \boldsymbol{\%}$ & $\mathbf{R}_{\mathbf{P b}} \%$ & $\mathbf{R}_{\mathbf{Z n}} \%$ & $\mathbf{R}_{\mathbf{C u}} \%$ \\
\hline Rough conc./Cu & 100,00 & 4,79 & 9,34 & 26,87 & 100,00 & 100,00 & 100,00 \\
Cleaned conc./Cu & 29,19 & $\mathbf{2 , 3 3}$ & $\mathbf{6 , 4 6}$ & $\mathbf{3 0 , 6 6}$ & 14,21 & 20,19 & $\mathbf{3 3 , 3 1}$ \\
Middling conc./Cu & 70,81 & 5,80 & 10,53 & 25,31 & 85,79 & 79,81 & 66,69 \\
\hline
\end{tabular}

Table 5 Exp. 3 Conc./Cu Metal balance

\begin{tabular}{cccccccc}
\hline Products & $\mathbf{W t}, \boldsymbol{\%}$ & $\mathbf{P b}, \boldsymbol{\%}$ & $\mathbf{Z n}, \boldsymbol{\%}$ & $\mathbf{C u}, \boldsymbol{\%}$ & $\mathbf{R P b}_{\mathbf{p b}} \%$ & $\mathbf{R z \mathbf { ~ }}_{\mathbf{1}}$ & $\mathbf{R}_{\mathbf{C u}} \%$ \\
\hline Rough conc./Cu & 100,00 & 4,63 & 7,36 & 26,53 & 100,00 & 100,00 & 100,00 \\
Cleaned conc./Cu & 44,94 & $\mathbf{2 , 4 1}$ & $\mathbf{6 , 7 4}$ & $\mathbf{3 0 , 8 1}$ & 23,40 & 41,17 & $\mathbf{5 2 , 2 0}$ \\
Middling conc./Cu & 55,06 & 6,44 & 7,86 & 23,03 & 76,60 & 58,83 & 47,80 \\
\hline
\end{tabular}

Based on results obtained in this copper minerals flotation experiments the following can be concluded:

An increase in copper content from $27,03 \%$ to $29,04 \%$ of $\mathrm{Cu}$ in copper concentrate was achieved during concentrate cleaning in period of $\mathrm{t}=1 \mathrm{~min}$. Lead content was decreased from $4,86 \%$ to $2,65 \%$ of $\mathrm{Pb}$ and zinc content was increased from 5,31\% to $9,69 \%$ of $\mathrm{Zn}$. Also, copper recovery in concentrate was $14,46 \%$ of $\mathrm{Cu}$, zinc recovery was $24,56 \%$ of $\mathrm{Zn}$ and lead recovery was $7,34 \%$ of $\mathrm{Pb}$. 
By increasing the cleaning time to $t=2 \mathrm{~min}$ an increase of copper content from $29,04 \%$ to $30,66 \%$ of $\mathrm{Cu}$ in copper concentrate was achieved. Lead content was decreased to $2,33 \%$ of $\mathrm{Pb}$ and zinc content was decreased to $6,46 \%$ of $\mathrm{Zn}$. Copper recovery in concentrate was $33,31 \%$ of $\mathrm{Cu}$, zinc recovery was $20,19 \%$ of $\mathrm{Zn}$ and lead recovery was $14,21 \%$ of $\mathrm{Pb}$.

By increasing the cleaning time to $\mathrm{t}=3 \mathrm{~min}$ a insignificant increase of copper content in concentrate to $30,81 \%$ of $\mathrm{Cu}$ was achieved. Lead content was decreased to $2,41 \%$ of $\mathrm{Pb}$ and zinc content was decreased from $7,36 \%$ to $6,74 \%$ of $\mathrm{Zn}$. Copper recovery in concentrate was $52,20 \%$ of $\mathrm{Cu}$, zinc recovery was $41,17 \%$ of $\mathrm{Zn}$ and lead recovery was $23,40 \%$ of $\mathrm{Pb}$.

These results are graphically presented in Fig. 2.

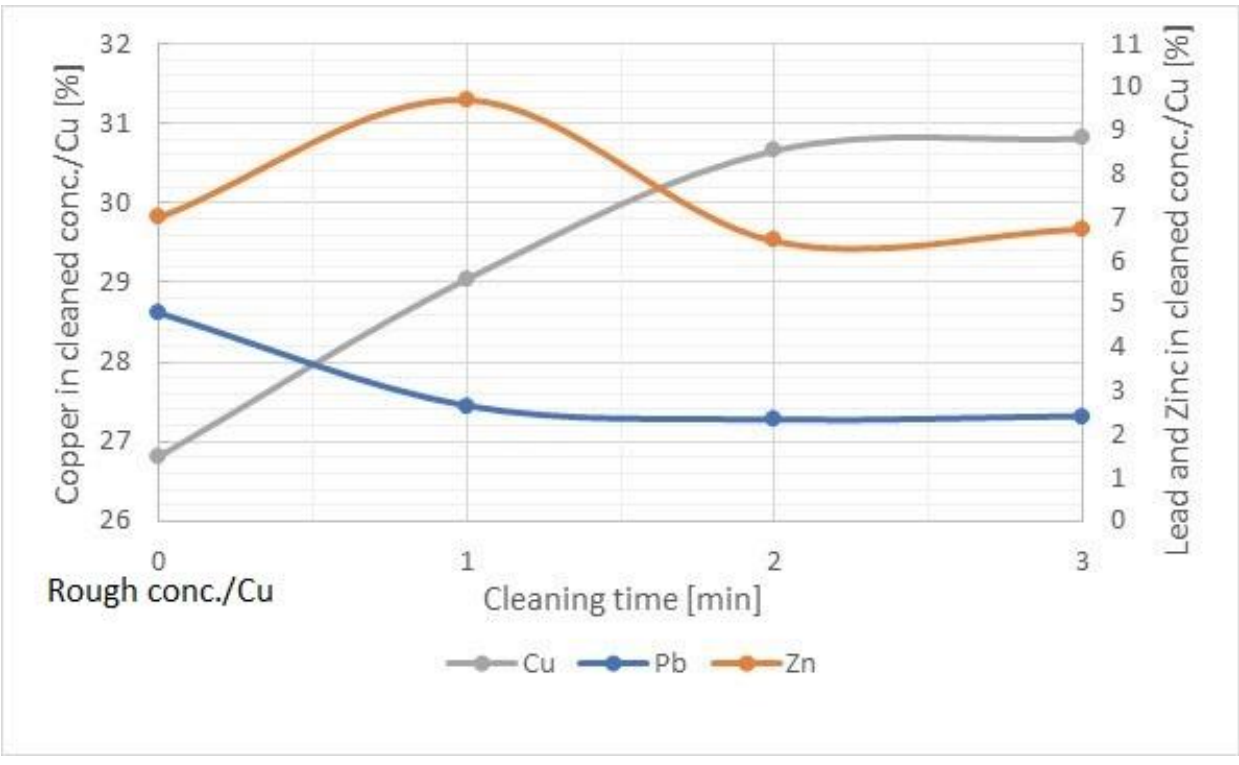

Figure 2 Metals content in Cleaned conc./Cu

\section{CONCLUSION}

Based on presented results the following can be concluded:

- Copper concentrate is composed of relatively small particles size, $\mathrm{d}_{95}$ is approximately $0,082 \mathrm{~mm}$ and $\mathrm{d}_{50}$ is approximately $0,05 \mathrm{~mm}$. Size fraction $-0,009$ $\mathrm{mm}$ participation in copper concentrate is $9 \%$ by weight, and this size fraction has poorly flotation properties.

- According to metal and mineral distribution by size fraction in copper concentrate, in $-0,009+0 \mathrm{~mm}$ fraction chalcopyrite $\left(\mathrm{CuFeS}_{2}\right)$ recovery is 
approximately $10 \%$, sphalerite $(\mathrm{ZnS})$ recovery is approximately $7,5 \%$ and galena $(\mathrm{PbS})$ recovery is approximately $20 \%$.

- The highest mineral recovery in copper concentrate is recorded in $-0,074+0,038$ $\mathrm{mm}$ fraction, approximately $60 \%$ of $\mathrm{CuFeS}_{2}$, approximately $57 \%$ of $\mathrm{ZnS}$ and approximately $44,5 \%$ of $\mathrm{PbS}$. As assumed, the highest minerals recovery in copper concentrate is in $-0,074+0,038 \mathrm{~mm}$ fraction, because this fraction is the most suitable for industrial scale flotation. Mineralogical analysis results show that harmful elements in copper concentrate (galena and sphalerite) are present in form of intergrowth particles with chalcopyrite, tailings minerals and each other. Liberated particles are also present, especially galena, which indicates a possibility of copper concentrate quality rising by removing those harmful minerals particles.

Research results showed that by applying one additional stage of copper concentrate cleaning $(\operatorname{Rough} / \mathrm{Cu})$, in duration of $\mathrm{t}=2 \mathrm{~min}$, quality of copper concentrate can be improved, especially in terms of lowering content of harmful penalizing elements in copper concentrate: from $4,5 \%$ to approximately $2,5 \%$ of galena and from approximately $7 \%$ to $6 \%$ or less of zinc.

\section{REFERANCES}

ATA, S. and JAMESON G. (2013) Recovery of coarse particles in the froth phase - A case study, Minerals Engineering, Vol. 69, pp 121-127

BOURNIVAL, G., ATA S. and JAMESON G. (2014) The influence of submicron particles and salt on the recovery of coarse particles, Minerals Engineering, Vol. 69, pp $146-153$

BULATOVIĆ, S. (2007) Handbook of flotation reagents, Elsevier Science \& Technology Books, pp 367-400

CHEN, W. et al. (2019) The selective flotation of chalcopyrite against galena using alginate as a depressant, Minerals Engineering, vol. 141, Article 105848

CVETIĆANIN, L., (2017), Effect of galena grain size on flotation kinetics, Thesis $(\mathrm{PhD})$, University of Belgrade

FRIEDBERG, H. S. and ROBINSON T. (2015) Tackling impurities in copper concentrates, Teck Resources Limited, [Online] Available from: https://www.teck.com/media/Tackling-Impurities-in-Copper-Concentrates.pdf [Accessed 19.09.2019.]

GEORGE P., NGUYEN A. and JAMESON G. (2004) Assessment of true flotation and entrainment in the flotation of submicron particles by fine bubbles, Minerals Engineering, 17, pp 847-853 
GONTIJO, C., FORNASIERO, D. and RALSTON, J. (2007) The Limits of Fine and Coarse Particle Flotation, The Canadian Journal of Chemical Engineering, Vol. 85, pp 739-747

JAMESON, G. and EMER, C. (2019) Coarse chalcopyrite recovery in a universal froth flotation machine, Minerals Engineering, Vol. 134, pp 118-133

KOHMUENCH, J. et al. (2018) Improving coarse particle flotation using the HydroFloat $^{\mathrm{TM}}$ (raising the trunk of the elephant curve), Minerals Engineering, Vol. 121, pp 137-145

KOSTOVIĆ, M. et al. (2015) Factorial design of selective flotation of chalcopyrite from copper sulfides, Journal of Mining Science, Vol. 51, No. 2, pp. 380-388,

LAZIĆ, P. (2014) Processing of lead and zinc ore, In: Serbian mining and geology in the second half of the XX century, VUJIC S. (editor), Academy of Engineering Sciences of Serbia, Matica srpska, Mining Institute Belgrade, pp 479-495

LAZIĆ, P. et al. (2004) Optimization of the flotation process of $\mathrm{Pb}-\mathrm{Cu}-\mathrm{Zn}$ ore from „Rudnik“ mine, Belgrade, Faculty of Mining and Geology, (Project ETR.6.01.0034BSerbian language)

LAZIĆ, P. et al. (2004) Possibilities of improving the quality of lead, copper and zinc concentrates with special reference to the possibility of reducing penalizing elements in copper concentrate, Belgrade, Faculty of Mining and Geology, (Study-Serbian language)

LAZIĆ, P. et al. (2007), Energy efficiency rising of flotation plant of "Rudnik" mine, Belgrade, Faculty of Mining and Geology, (Project EE232026-Serbian language)

LAZIĆ, P. et al. (2010), Direct selective lead, copper and zinc minerals flotation from polymetallic ore "Podvirovi", Journal of Mining Science, Vol. 46, No. 6, pp 690-694

LEPPINEN, J., HINTIKKA V. and KALAPUDAS R. (1998) Effect of electrochemical control on selective flotation of copper and zinc from complex ores, Minerals Engineering, Vol. 11, No. 1, pp 39-51

LONG, G., PENG, Y. and BRADSHAW D. (2014) Flotation separation of copper sulphides from arsenic minerals at Rosebery copper concentrator, Minerals Engineering, Vol. 66-68, pp 207-214

MANKOSA, M. et al. (2018), Improving fine particle flotation using the StackCell ${ }^{\mathrm{TM}}$ (raising the tail of the elephant curve), Minerals Engineering, Vol. 121, pp 83-89

RAN, J. et al. (2019), Effects of particle size on flotation performance in the separation of copper, gold and lead, Powder Technology 344, pp 654-664 
TOMANEC, R. and LAZIĆ, P. (2012) Mineral composition of sulphide-oxide Pb - Zn ore from Rudnik mine, Podzemni radovi, vol. 21, pp. 151-159

TOMANEC, R. (2000) Examinations methods of mineral resources in mineral processing, Belgrade, Faculty of Mining and Geology

TOMANEC, R., (2011), Ore microscopic examination of raw material samples from exploration wells at the "Rudnik" mine, Rudnik, FSD of "Rudnik" mine

TOMANEC, R. et al. (2012) Characteristics and the possibility of concentration of lowgrade oxide $\mathrm{Pb}-\mathrm{Zn}$ ore from Rudnik mine. In: Proceedings of XVI International Conference on Waste Recycling, V̌̌B, Technicka Univerzita Ostrava, Ostrava. Czech Republic. pp. 179-185

TOMANEC, R. et al. (2013), Ore Microscopy Analysis Methods In Mineral Concentration Processis. In: Proceedings of 5Th Jubilee Balkanmine Congress and Comercial Exhibition, Ohrid, Macedonia. pp. 779-785

WEIDENBACH M., DUNN G. and TEO, Y., (2016), Removal of impurities from copper sulfide mineral concentrates. In: ALTA, Perth, 21-28 May, [Online] Available from: $\quad$ https://orway.com.au/wp-content/uploads/2016/07/ALTA-2016-NCC-OzMinerals-Orway-Mineral-Consultants.pdf [Accessed 19.09.2019.]

ZANIN M., LAMBERT, H. and PLESSIS, C., (2019), Lime use and functionality in sulphide mineral flotation: A review, Minerals Engineering, Vol. 143, Article 105922 